\title{
Investigation of Passive Design Techniques for Pitched Roof Systems in the Tropical Region
}

\author{
Karam M. Al-Obaidi ${ }^{1}$, Mazran Ismail ${ }^{1} \&$ Abdul Malek Abdul Rahman ${ }^{1}$ \\ ${ }^{1}$ School of Housing, Building and Planning, Universiti Sains Malaysia, 11800, Penang, Malaysia \\ Correspondence: Karam M. Al-Obaidi, School of Housing, Building and Planning, Universiti Sains Malaysia, \\ 11800, Penang, Malaysia. Tel: 60-174-039-378. E-mail: karam_arc@yahoo.com
}

Received: March 13, 2014

Accepted: April 1, $2014 \quad$ Online Published: May 5, 2014

doi:10.5539/mas.v8n3p182

URL: http://dx.doi.org/10.5539/mas.v8n3p182

\begin{abstract}
Pitched roof design represents the common system for the most tropical houses in Malaysia. Different angles and colours of this roof deliver various impacts on the indoor environment. This study focuses on estimating the amount of heat gain and roof surface temperature obtained from different roofing aspects. The paper hypothesizes that colour technique could change pitched roof design more than roof angles and materials. The research was based on simulation analysis applied on an actual room size with different roof angles $\left(0^{\circ}, 30^{\circ}, 45^{\circ}\right.$ and $60^{\circ}$ ) in the Malaysian environment. As a result, the findings of different roofing systems affirm the hypothesis and show the significant of roof colour compare to area, angles and materials. This study contributes efficiently to the knowledge of the roofing design in the tropics. In addition, it will shed light on the economic sector and sustainability for optimum roofing concept particularly for low cost housing components in Malaysia.
\end{abstract}

Keywords: pitched roofs, roof angles, roof colours, roof materials, tropical houses

\section{Introduction}

Research studies have estimated that urban areas could be covered by $60 \%$ of roofs and pavements (Akbari, Arthur, \& Rosenfeld, 2008). In addition, this estimation is increasing as there are around $50 \%$ of the world population currently in urban regions, with expected increases to $70 \%$ at the end of 2040 . Furthermore, roofing systems represent the main body of urban area that interact directly with solar rays. Therefore, roof angles and claddings are one of the most elements that may lead to effect considerably the indoor environment. Generally, pitched roof system represents the most common construction design for traditional and modern buildings in hot humid regions. This type of roof has been extensively used in order to protect against rain water and strong sunshine as well as its consequent of lower heat transfer into the building. The rapid development of building design were the reason for the selection of concrete tiles, cement tiles, clay tiles and aluminium sheets for this type of system in the specific environment. However, concrete and cement tiles have the priority in the Malaysian urban area not due to thermal properties but because of low cost and good resistance to the weather conditions.

The climatic condition, sun position, orientation, tilt of building external elements, surface reflectance, thermal capacity, area of the surface must be considered in evaluating heat gain (Mahdavinejad, Ghasempourabadi, Nikhoosh, \& Ghaedi, 2012). According to Vijaykumar, Srinivasan and Dhandapani (2007) indicate that roofing system represents $70 \%$ of the total heat gain in a building. The colour of the external surfaces especially the roof has a remarkable effect on the level of heat gain in buildings and on the indoor temperature, particularly in unair-conditioned spaces. This technique is widely recognized and clearly observed in the hot regions, but its application is poor in the tropics. Based on a study in Malaysia conducted by Yacouby, Khamidi, Nuruddin, Farhan and Razali (2011), the results indicated that the majority roof tiles colours are dark as Red 38\%, Brown 25.9\%, White 9.5\%, Beige and Blue 7.8\% Black 4.9\% and Grey 2.9\%. In Malaysia, Allen et al. (2008) showed that concrete roof tiles are the most commonly used roofing materials, as it represents $85 \%$ followed by clay tiles and metal deck with $10 \%$ and 5\% respectively. Yacouby, Khamidi, Nuruddin, Farhan, \& Razali (2011) tested two roof slopes $30^{\circ}$ and $45^{\circ}$ consist of concrete and clay tiles which are commonly used in Malaysia.

Experimental and Numerical researches in buildings in the United States as well as in Europe (Bozonnet, Doya, \& Allard, 2011; Pisello \& Cotana, 2013) indicated the reduction of the cooling peak load by up to $70 \%$ and of the indoor free-floating temperature up to $3^{\circ} \mathrm{C}$ in the thermal zones adjacent to the roof features implementation. 
Pearlmutter (1993) made the first attempt to quantitatively compare thermal behaviour of several roof designs in terms of indoor temperatures. Runsheng, Meir and Etzion (2003) compared the amount of solar heat to domed roofs and flat roofs. The authors stated that the ratio of radiation absorbed by a curved roof to that absorbed by a flat one rises with increase of rim angle however it is insignificantly affected by climate characteristics and site latitude. Hadavand, Yaghoubi and Emdad (2007) in another study compared flow field around different building geometries of several roofs and also determined corresponding heat flow and Nusselt number for these roofs. According to Hadavand and Yaghoubi (2008) temperature difference of two sides of vaulted roofs increases with rim angle. Fitzgerald et al. (2011) have studied on the assessment of roof space solar gains in a temperate maritime climate. Al-Obaidi, Ismail and Abdul Rahman (2014) reviewed the performance of pitched roof angles and pitched roof with an attic in the tropics.

In addition, Jayasinghe, Attalage and Jayawardena (2003) investigated roof orientation, roofing materials and roof surface colour: their influence on indoor thermal comfort in warm humid climates. The recommendations stated in this study have lead to; (i) The effect of the roof orientation on indoor thermal conditions is insignificant. (ii) Prefer clay tiles to cement fibre sheets as a roof covering material. (iii) An improvement can be obtained by using an aluminium foil with or without polystyrene over the ceiling. (iv) Paint the exterior surface of the roof with a light colour such as off-white, especially if the roof covering is cement fibre sheets. In Malaysia, Al-Obaidi, Ismail and Abdul Rahman (2013) tested the effect of pitched roof integrated with aluminium sheet and reflective roof however this study was based on determine the level of daylight and heat gain from skylight system. Moreover, Rahman, Rahim, Al-Obaidi, Ismail and Mui (2013) investigated the performance of affordable housing design in the tropics which targeted with the cement roof tiles for a single story low cost terrace house. However both studies have not compared different types of roofs.

As a result, most of researchers have not shed light on the investigation of heat gain with roof angles associated with different colours and materials. Therefore, this paper hypothesizes that colour technique could change pitched roof design more than roof angles and materials. Therefore, this paper targets the roof construction system (structure angles, colours and materials) as keys to identify the design controllers. The paper aims to investigate these properties in same room size to shift the paradigm in the understanding of passive roofing design in the tropical architecture.

\section{Methodology}

The study was conducted on several roof types applied on a single room in the area of Penang (latitude $5.3^{\circ}$ and longitude $100.3^{\circ}$ ), Malaysia. The testing room was constructed from brickwork for the walls and exposed to full sunlight from all directions. The long side of the room was oriented to east and west side to experience worst case condition. The investigational work consists of one unit experimental model of $5.0 \mathrm{~m}(\mathrm{~L}) \times 4.0 \mathrm{~m}(\mathrm{~W})$ and $3.0 \mathrm{~m}(\mathrm{H})$ contains of a door without any windows as shown in Figure 1 the door was shut during the measurement for eliminating any additional heat gain. The floor was covered with cement sand screed. External walls were constructed with thick brick. External and internal walls were white paint finish.

The experimental work was conducted on the same room size with different roof designs and mainly focusing on two different roofing materials i.e. clay tiles and aluminum sheets which are commonly used in Malaysia. The above parameters were tested for flat and sloped roofs $0^{\circ}\left(20 \mathrm{~m}^{2}\right), 30^{\circ}\left(47 \mathrm{~m}^{2}\right), 45^{\circ}\left(56 \mathrm{~m}^{2}\right), 60^{\circ}\left(73 \mathrm{~m}^{2}\right)$. In addition, three types of roof colours selected as Black, Red and White to represents different solar reflectance from 0.9 to 0.2 . The thicknesses of roof materials were clay tiles $15 \mathrm{~mm}$ with cement board $3 \mathrm{~mm}$ while aluminum sheets used $0.8 \mathrm{~mm}$. The measurement targeted outdoor and indoor environments i.e. outdoor air temperature, solar radiation, surface temperature, indoor air temperature were measured to evaluate the thermal performance of the room under the roofs. 


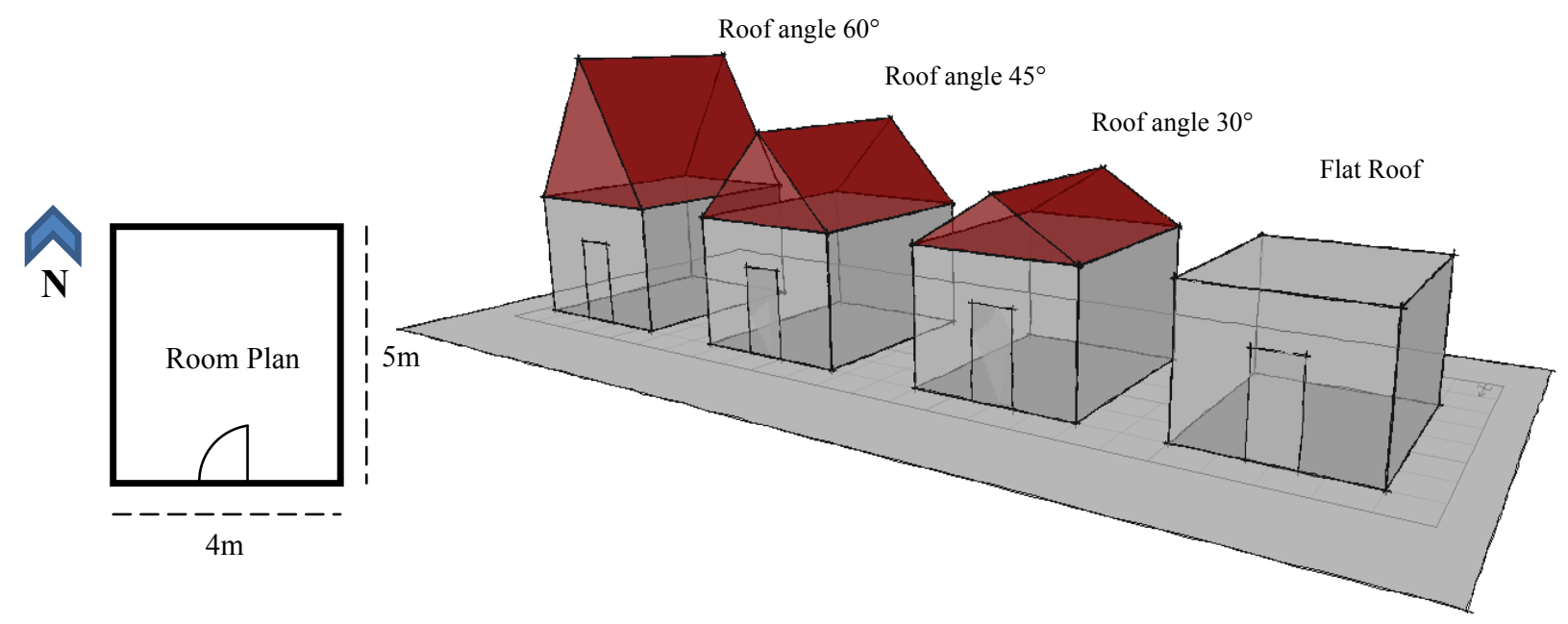

Figure 1. Graphical models

The findings were obtained using the building energy simulation tool "Integrated Environmental Solutions" $<$ Virtual Environment $>$ version 6.4 (IES, 2013) used for the investigations. The simulation program is recommended for the Malaysian conditions by Green Building Index (2011) and Building Sector Energy Efficiency Project (2013). The weather data used for the simulation study is the Test Reference Year (TRY) weather data from an analysis of 21 years of weather data from the weather station of Penang Airport in Bayan Lepas, Malaysia. The selected days for the measurement were based on targeting the hottest days of the year (mid of March) to compare the different types of roofs for constant evaluation. Due to the large amount of information generated, this paper only reports the reading of 14th March as the hottest day to perform the testing for several types of investigations. The data presents the maximum outdoor air temperature which was around $34.6{ }^{\circ} \mathrm{C}$ while maximum outdoor solar radiation was around $1060 \mathrm{~W} / \mathrm{m}^{2}$. These readings demonstrate the most common levels of the current condition.

\section{Results and Discussion}

\subsection{The Performance of Roof with Clay Tiles}

Figure 2 shows the indoor temperature for roof with clay tiles in different roof colours and angles. The results indicate that in various roof colours the behaviour of roof angle was varied significantly. It was noticed that the indoor temperature with Black colour $0^{\circ}$ angle represents the highest level whereas with White colour shows the lowest. These performances give an interesting understanding to the design of roofing systems. The readings show that maximum indoor air temperature with Black roof was $40.06{ }^{\circ} \mathrm{C}$ for roof $\left(60^{\circ}\right), 39.9^{\circ} \mathrm{C}$ for roof $\left(45^{\circ}\right)$, $40.17{ }^{\circ} \mathrm{C}$ for roof $\left(30^{\circ}\right)$ and $40.61{ }^{\circ} \mathrm{C}$ for roof $\left(0^{\circ}\right)$. For Red colour was $36.13{ }^{\circ} \mathrm{C}$ for roof $\left(60^{\circ}\right), 35.69^{\circ} \mathrm{C}$ for roof $\left(45^{\circ}\right), 35.64{ }^{\circ} \mathrm{C}$ for roof $\left(30^{\circ}\right)$ and $35.81{ }^{\circ} \mathrm{C}$ for roof $\left(0^{\circ}\right)$. For the White colour was $33.32^{\circ} \mathrm{C}$ for roof $\left(60^{\circ}\right)$, $32.76^{\circ} \mathrm{C}$ for roof $\left(45^{\circ}\right), 32.49^{\circ} \mathrm{C}$ for roof $\left(30^{\circ}\right)$ and $32.46^{\circ} \mathrm{C}$ for roof $\left(0^{\circ}\right)$. The readings show that colours play a significant role in every roof angle more than material properties and roof shapes. The findings show that the difference of maximum - minimum indoor temperature with same colour but with different angles was for Black colour with angle $0^{\circ}-45^{\circ}$ was $0.71{ }^{\circ} \mathrm{C}\left(40.61\right.$ - 39.9). For Red colour with angle $60^{\circ}$ - $30^{\circ}$ was $0.49{ }^{\circ} \mathrm{C}(36.13$ $35.64)$ and for White colour with angle $60^{\circ}-0^{\circ}$ was $0.85^{\circ} \mathrm{C}(33.32-32.46)$. The readings show that in every colour the maximum and minimum readings were for different roof angles. This findings approved that roof colour is important compare to roof angles. The reading show that the maximum value recorded for Black - Red roof colour was $4.48{ }^{\circ} \mathrm{C}\left(40.61\right.$ - 36.13) and for Black - White roof colour was $7.29^{\circ} \mathrm{C}(40.61$ - 33.32). Table 1 tabulated the main indoor temperature for worst and best conditions with different roof angles. 


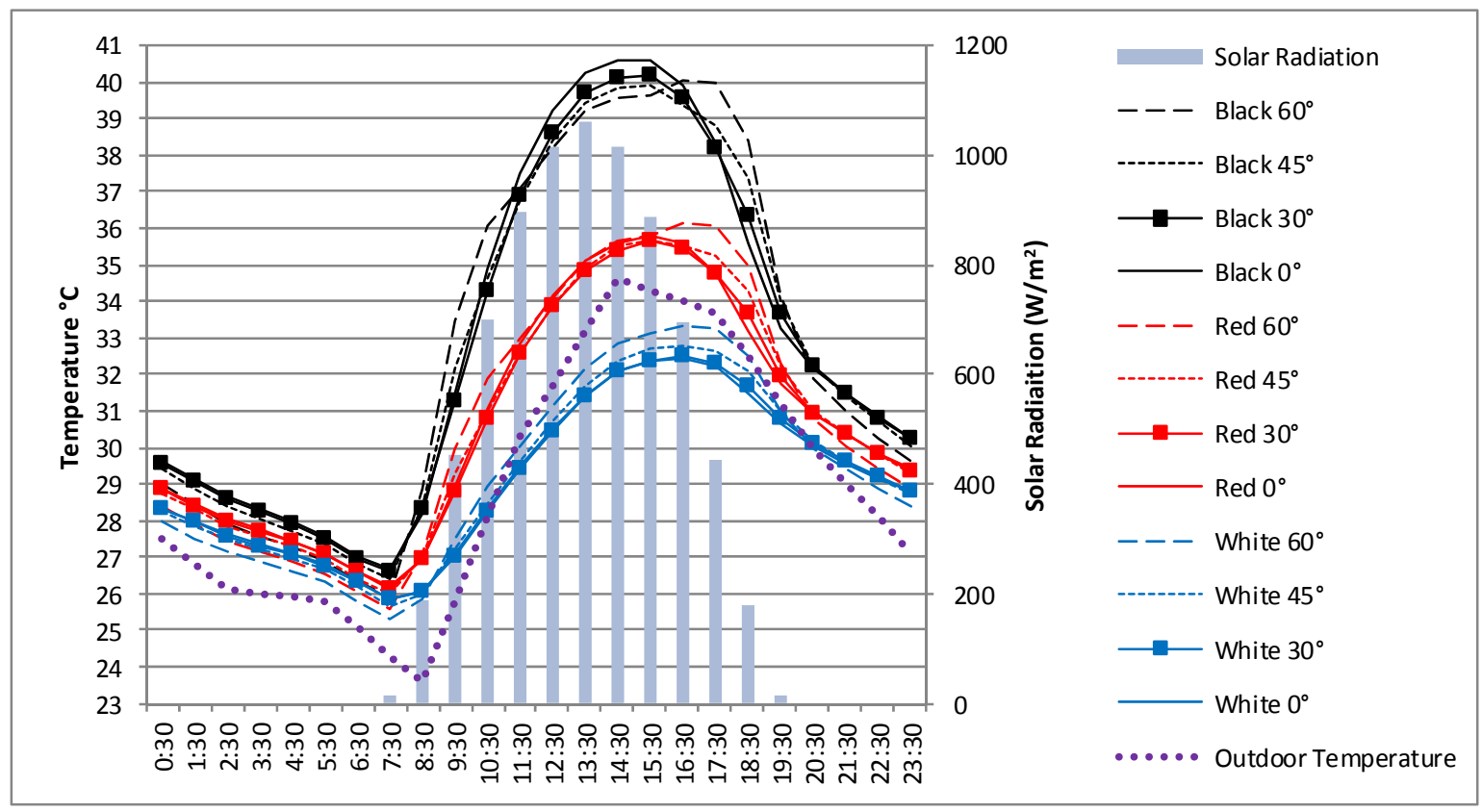

Figure 2. Indoor temperature for roof with clay tiles associated with different roof angles and colours

Table 1. Indoor temperature for roof (clay tiles) in Black and White colours with different roof angles

\begin{tabular}{ccccccccc}
\hline & Black 60 $^{\circ}$ & Black 45 $^{\circ}$ & Black 30 $^{\circ}$ & Black 0 $^{\circ}$ & White 60 $^{\circ}$ & White 45 $^{\circ}$ & White 30 $^{\circ}$ & White $^{\circ}$ \\
\hline Max & 40.06 & 39.9 & 40.17 & 40.61 & 33.32 & 32.76 & 32.49 & 32.46 \\
Mean & 32.78 & 32.77 & 32.76 & 32.89 & 29.24 & 29.22 & 29.14 & 29.13 \\
Min & 25.94 & 26.37 & 26.58 & 26.65 & 25.29 & 25.68 & 25.84 & 25.86 \\
\hline
\end{tabular}

Figure 3, Figure 4 and Figure 5 present the behaviour of clay tiles surface temperature with various roof angles and colours. The readings indicate varied patterns. Figure 3 shows that roof with Black colour, the maximum surface temperature was for flat roof $0^{\circ}$ which it reached $57.45^{\circ} \mathrm{C}$ around $01: 30 \mathrm{pm}$. However, for other roof angles the two sides was not stable as the highest temperature recorded for the east side more than west side. The findings for Black colour show that roof angle $\left(60^{\circ}\right)$ east side was $55.52{ }^{\circ} \mathrm{C}$ and west side was lower with $55.27^{\circ} \mathrm{C}$, roof angle $\left(45^{\circ}\right)$ east side was $55.64^{\circ} \mathrm{C}$ and west side was lower with $55.13^{\circ} \mathrm{C}$, for roof angle $\left(30^{\circ}\right)$ east side was $55.74^{\circ} \mathrm{C}$ and west side was also lower with $55.26^{\circ} \mathrm{C}$ and finally roof angle $\left(0^{\circ}\right)$ was the highest with $57.45^{\circ} \mathrm{C}$.

The results from Figure 4 show the performance of clay tiles surface temperature for Red colour which presents varied patterns for east and west side. The maximum surface temperature was for roof angle $60^{\circ}$ which it extended to $45{ }^{\circ} \mathrm{C}$ around 04:30 pm. However, the comparison of two sides shows that west side was always higher than east side. The findings point out that maximum reading for roof angle $\left(60^{\circ}\right)$ east side was $43.19^{\circ} \mathrm{C}$ while west side was $45.01^{\circ} \mathrm{C}$, roof angle $\left(45^{\circ}\right.$ ) east side was $43.65^{\circ} \mathrm{C}$ while west side was $44.84^{\circ} \mathrm{C}$, for roof angle $\left(30^{\circ}\right)$ east side was $43.58^{\circ} \mathrm{C}$ while west side was $44.68^{\circ} \mathrm{C}$ and finally roof angle $\left(0^{\circ}\right)$ was $44.54^{\circ} \mathrm{C}$. The readings show that even roof angle $\left(60^{\circ}\right)$ was recorded highest temperature however the east side of this roof was lower than roof angle of $45^{\circ}$ and $30^{\circ}$.

Figure 5 also shows different patterns for east and west side for White colour. The maximum surface temperature was for roof angle $60^{\circ}$ which hit $37.69^{\circ} \mathrm{C}$ between 03:30 pm and 04:30 pm. However, the figure shows that west side was significantly higher than east side. The outcomes indicate that maximum reading for roof angle $\left(60^{\circ}\right)$ east side was $35.96^{\circ} \mathrm{C}$ while west side was higher with $37.69^{\circ} \mathrm{C}$, roof angle $\left(45^{\circ}\right)$ east side was $36.14{ }^{\circ} \mathrm{C}$ while west side was higher with $37.49{ }^{\circ} \mathrm{C}$, for roof angle $\left(30^{\circ}\right)$ east side was $36.16^{\circ} \mathrm{C}$ whereas west side was $37.13{ }^{\circ} \mathrm{C}$ and finally roof angle $\left(0^{\circ}\right)$ was $35.35^{\circ} \mathrm{C}$. The recording results in Table 2 affirm that even roof angle $\left(60^{\circ}\right)$ was recorded highest temperature however the east of this roof was lower than roof angle of $45^{\circ}$ and $30^{\circ}$. 


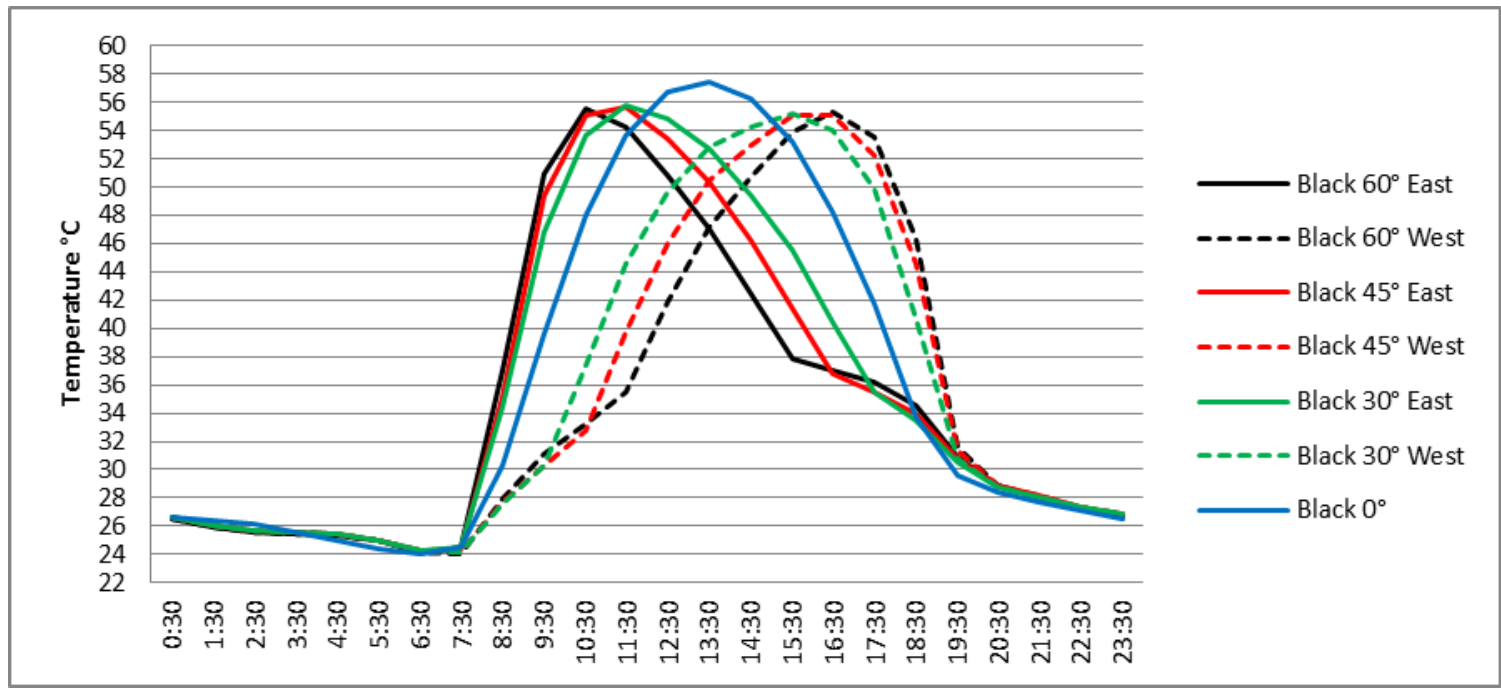

Figure 3. Surface temperature of clay tiles with Black colour in two sides (East and West)

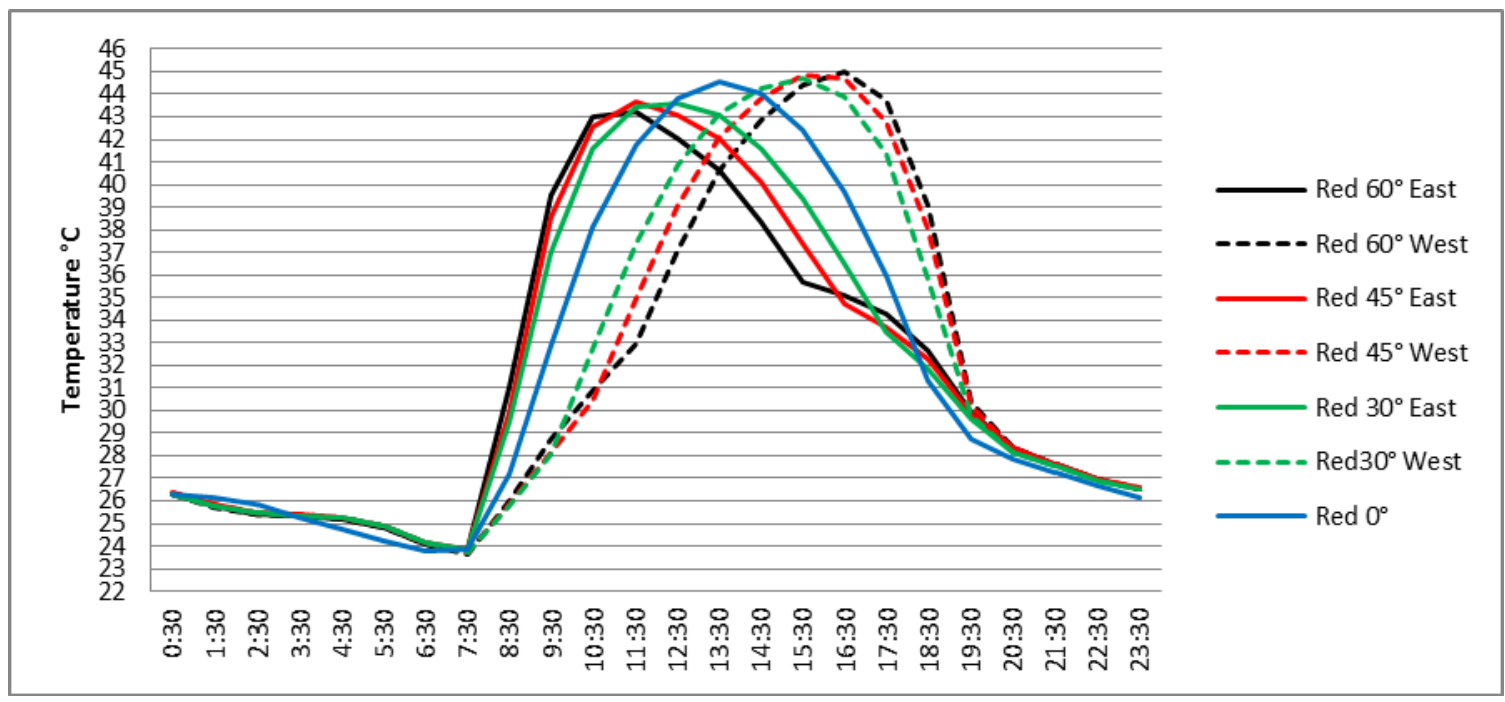

Figure 4. Surface temperature of clay tiles with Red colour in two sides (East and West)

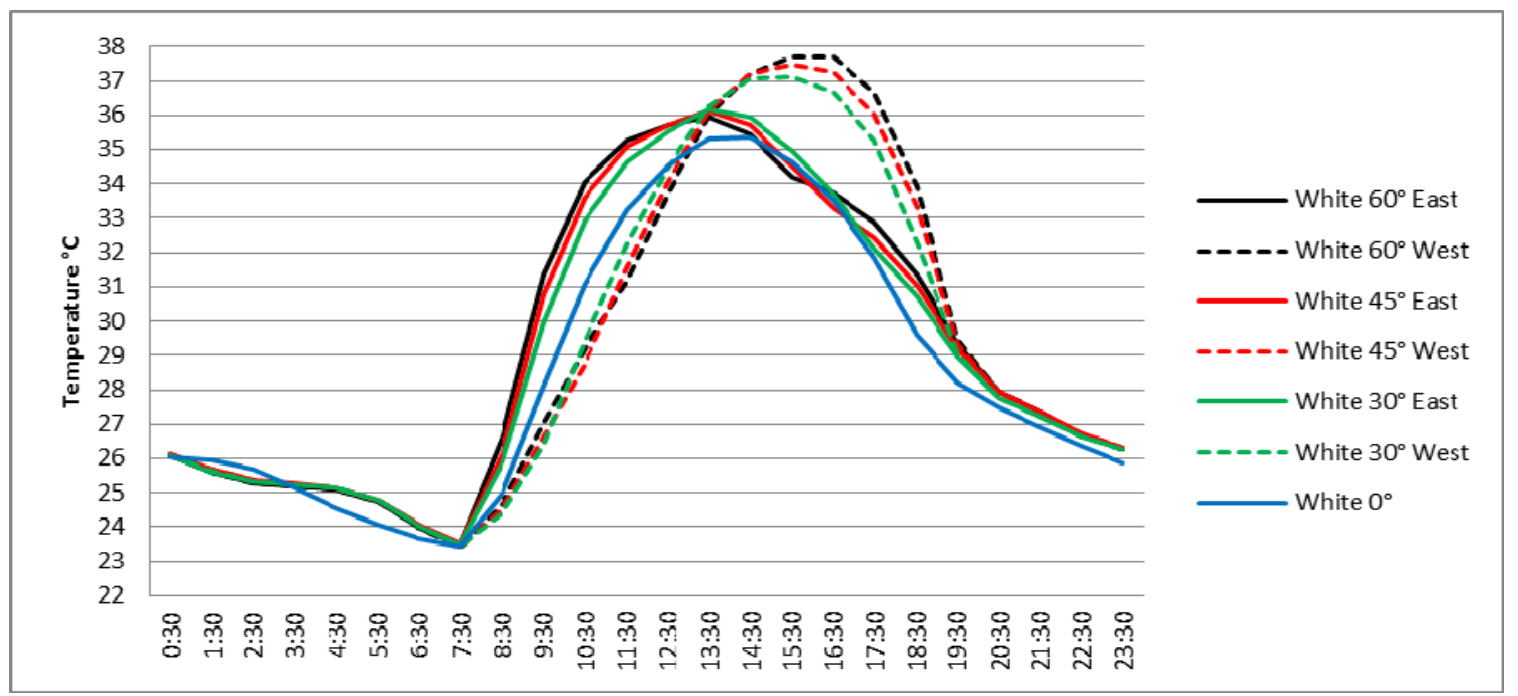

Figure 5. Surface temperature of clay tiles with White colour in two sides (East and West) 
Table 2. The performance of surface temperature $\left({ }^{\circ} \mathrm{C}\right)$ for clay tiles in worst and best conditions

\begin{tabular}{|c|c|c|c|c|c|c|c|c|c|c|c|c|c|c|}
\hline & 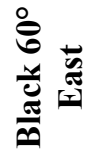 & 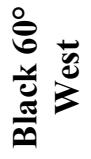 & 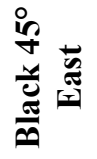 & 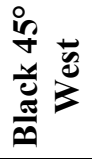 & 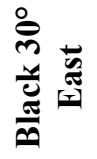 & 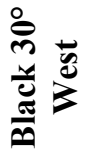 & $\begin{array}{l}\stackrel{\circ}{\theta} \\
\frac{y}{e} \\
\frac{\pi}{00}\end{array}$ & 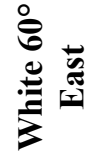 & 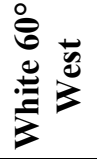 & 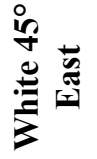 & 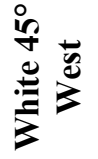 & 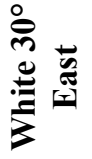 & 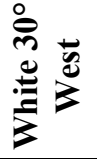 & $\begin{array}{l}\stackrel{\circ}{0} \\
\stackrel{\mathscr{O}}{3} \\
\dot{3}\end{array}$ \\
\hline$\sum^{\grave{J}}$ & 55.52 & 55.27 & 55.64 & 55.13 & 55.74 & 55.26 & 57.45 & 35.96 & 37.69 & 36.14 & 37.49 & 36.16 & 37.13 & 35.35 \\
\hline$\stackrel{\Xi}{\stackrel{\Xi}{ \pm}}$ & 34.51 & 34.22 & 34.92 & 34.68 & 35.3 & 35.05 & 35.86 & 29.32 & 29.25 & 29.25 & 29.19 & 29.12 & 29.09 & 28.57 \\
\hline$\Xi$ & 24.17 & 24.02 & 24.27 & 24.13 & 24.26 & 24.15 & 24.01 & 23.47 & 23.37 & 23.5 & 23.43 & 23.46 & 23.41 & 23.44 \\
\hline
\end{tabular}

\subsection{The Performance of Roof with Aluminium Sheets}

Figure 6 shows the indoor temperature for roof with aluminium sheets for different roof colours and angles. The results indicate that in various roof colours the behaviour of roof angle was varied considerably. It was observed that maximum indoor temperature with Black colour $0^{\circ}$ angle represent the highest reading whereas with White colour shows the lowest. The behaviour of different roofs gives an interesting indication. The findings show that maximum indoor air temperature with Black was $40.76^{\circ} \mathrm{C}$ for roof $\left(60^{\circ}\right), 40.81{ }^{\circ} \mathrm{C}$ for roof $\left(45^{\circ}\right), 41.13{ }^{\circ} \mathrm{C}$ for roof $\left(30^{\circ}\right)$ and $41.66{ }^{\circ} \mathrm{C}$ for roof $\left(0^{\circ}\right)$. For Red colour was $36.58{ }^{\circ} \mathrm{C}$ for roof $\left(60^{\circ}\right), 36.23{ }^{\circ} \mathrm{C}$ for roof $\left(45^{\circ}\right)$, $36.22{ }^{\circ} \mathrm{C}$ for roof $\left(30^{\circ}\right)$ and $36.4^{\circ} \mathrm{C}$ for roof $\left(0^{\circ}\right)$. For the White colour was $33.6^{\circ} \mathrm{C}$ for roof $\left(60^{\circ}\right), 33.02{ }^{\circ} \mathrm{C}$ for roof $\left(45^{\circ}\right), 32.75{ }^{\circ} \mathrm{C}$ for roof $\left(30^{\circ}\right)$ and $32.71{ }^{\circ} \mathrm{C}$ for roof $\left(0^{\circ}\right)$. Support the outcomes that mentioned earlier, the findings show that colours play a considerable role in every roof angle compare to property, area and shape. The findings indicate that the difference of maximum - minimum indoor temperature with same colour but with different angles was for Black colour with angle $0^{\circ}-60^{\circ}$ was $0.9^{\circ} \mathrm{C}(41.66$ - 40.76). For Red colour with angle $60^{\circ}-30^{\circ}$ was $0.36^{\circ} \mathrm{C}(36.58-36.22)$ and for White colour with angle $60^{\circ}-0^{\circ}$ was $0.89^{\circ} \mathrm{C}(33.6-32.71)$. In fact, the results show that minimum readings for aluminium sheets with Black colour was for roof angle $\left(60^{\circ}\right)$ while for the clay tiles was for roof angle $\left(45^{\circ}\right)$. The readings present that in every colour the maximum and minimum readings were for different roof angles. These outcomes approved that roof colour is more important than roof angles. The analysis show that the maximum value for Black - Red roof colour was $5.08{ }^{\circ} \mathrm{C}(41.66-36.58)$ and for Black - White roof colour was $8.06{ }^{\circ} \mathrm{C}(41.66$ - 33.6). Table 3 tabulated the main indoor temperature for worst and best conditions with different roof angles.

Table 3. Indoor temperature for roof (aluminium sheets) in Black and White colours with different roof angles

\begin{tabular}{ccccccccc}
\hline & Black 60 $^{\circ}$ & Black 45 $^{\circ}$ & Black 30 $^{\circ}$ & Black 0 $^{\circ}$ & White $^{6} \mathbf{0}^{\circ}$ & White 45 $^{\circ}$ & White 30 $^{\circ}$ & White $^{\circ}$ \\
\hline Max & 40.76 & 40.81 & 41.13 & 41.66 & 33.6 & 33.02 & 32.75 & 32.71 \\
Mean & 32.99 & 33.01 & 33.03 & 33.18 & 29.26 & 29.23 & 29.15 & 29.13 \\
Min & 25.74 & 26.18 & 26.4 & 26.47 & 25.1 & 25.49 & 25.64 & 25.67 \\
\hline
\end{tabular}




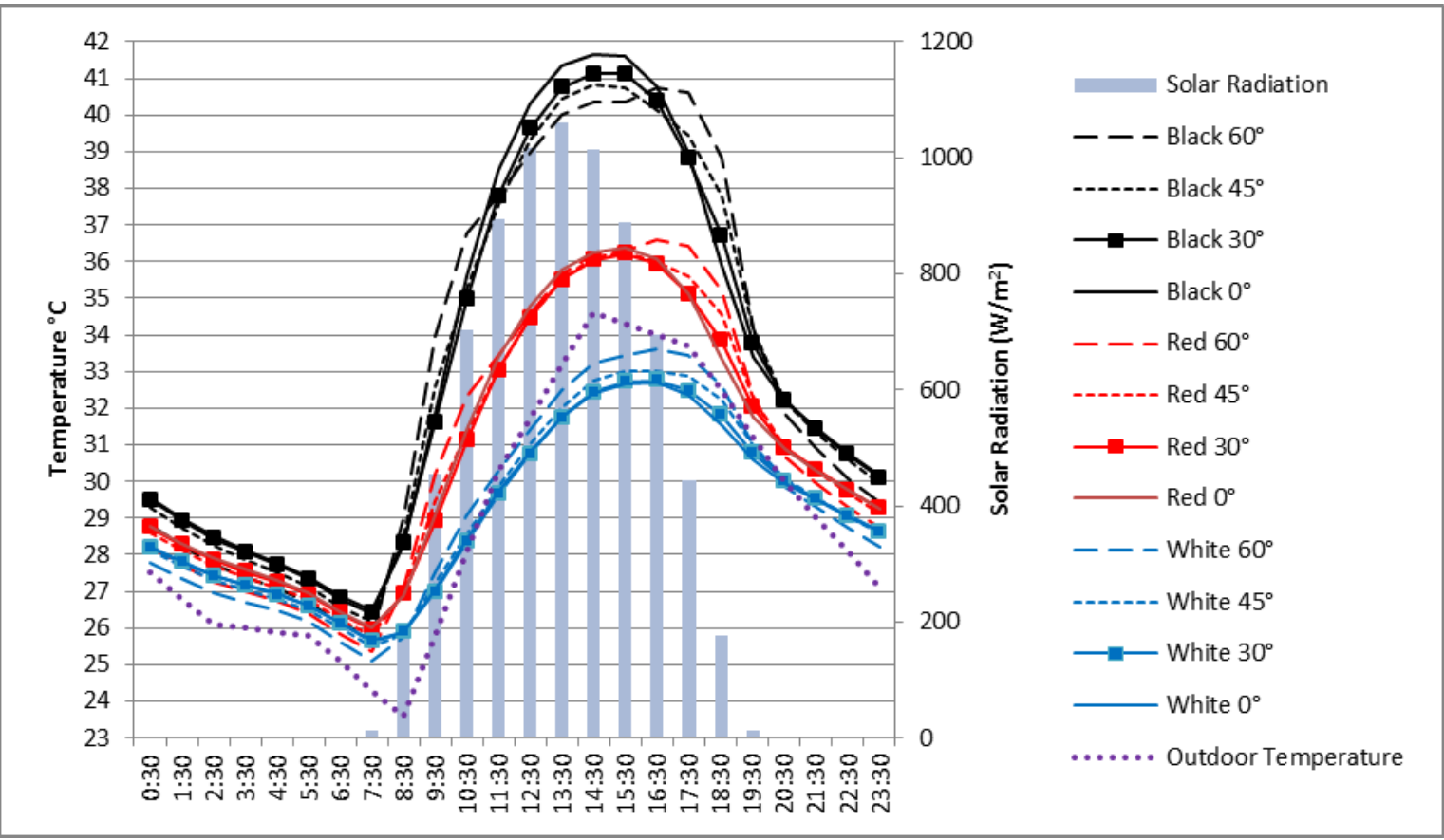

Figure 6. Indoor temperature for roof with aluminium sheets associated with different roof angles and colours

Figure 7, Figure 8 and Figure 9 present the behaviour of aluminium sheets surface temperature with various roof angles and colours. The readings draw varied patterns. Figure 7 indicates that roof with Black colour the maximum surface temperature was for flat roof $0^{\circ}$ which reached $60.15{ }^{\circ} \mathrm{C}$ around $01: 30 \mathrm{pm}$. However, the outcomes show that roof sides were also different as east side was higher than west side. The findings for Black colour show that roof angle $\left(60^{\circ}\right)$ east side was $58.49^{\circ} \mathrm{C}$ and west side was $57.75^{\circ} \mathrm{C}$, roof angle $\left(45^{\circ}\right)$ east side was $58.63{ }^{\circ} \mathrm{C}$ and west side was $57.68^{\circ} \mathrm{C}$, for roof angle $\left(30^{\circ}\right)$ east side was $58.73{ }^{\circ} \mathrm{C}$ and west side was $57.8^{\circ} \mathrm{C}$ and finally roof angle $\left(0^{\circ}\right)$ was $60.15^{\circ} \mathrm{C}$.

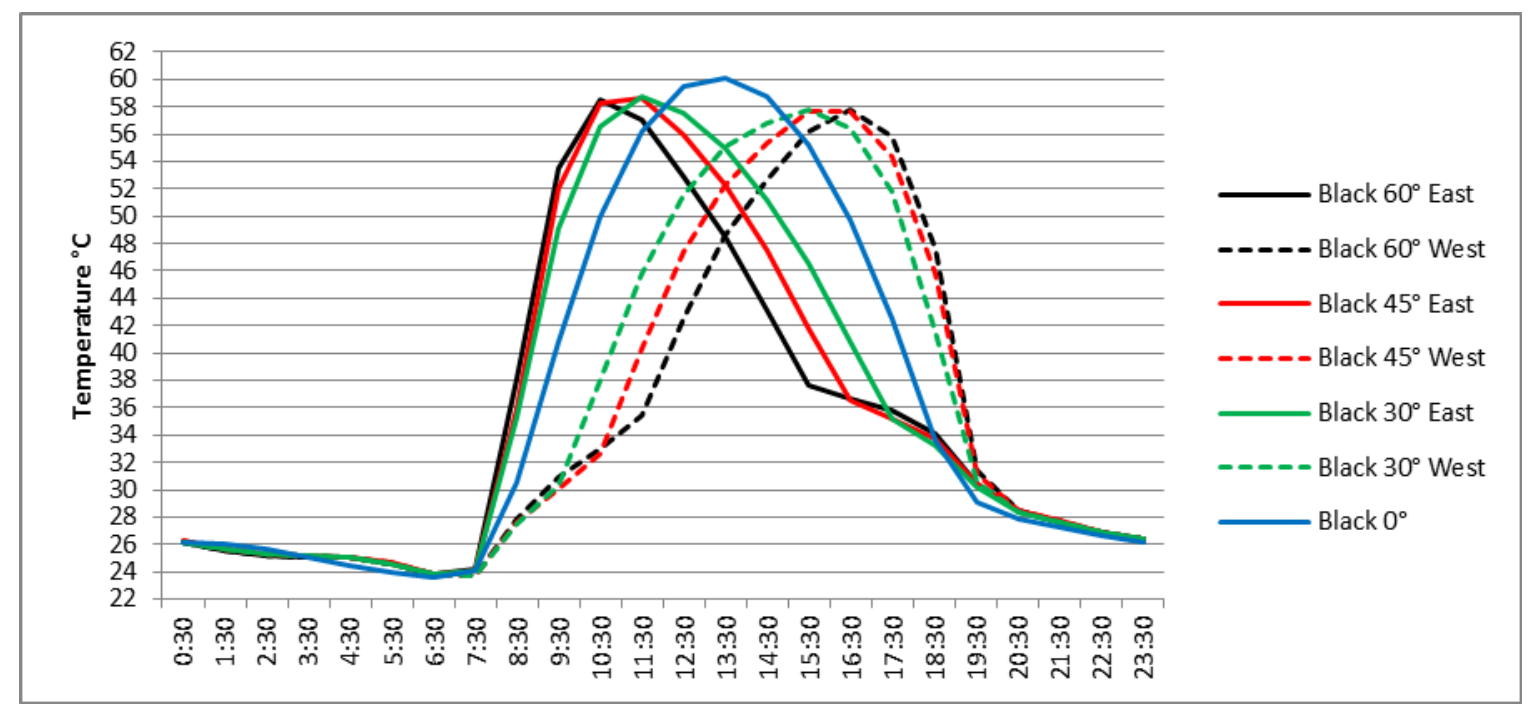

Figure 7. Surface temperature of aluminium sheets with Black colour in two sides (East and West)

Figure 8 shows the readings of surface temperature that painted with Red colour which indicate of varied patterns for east and west side. The maximum surface temperature was with roof angle $60^{\circ}$ which reached $46.47{ }^{\circ} \mathrm{C}$ around $04: 30 \mathrm{pm}$. In addition, the findings assert that two sides of roof were higher for west on contrary of the Black colour. The maximum reading for roof angle $\left(60^{\circ}\right)$ east side was $44.81{ }^{\circ} \mathrm{C}$ while it was 
higher for west side with $46.47^{\circ} \mathrm{C}$, roof angle $\left(45^{\circ}\right)$ east side was $45.39^{\circ} \mathrm{C}$ while it was higher for west side with $46.38^{\circ} \mathrm{C}$, for roof angle $\left(30^{\circ}\right)$ east side was $45.19^{\circ} \mathrm{C}$ while it was higher for west side with $46.21^{\circ} \mathrm{C}$ and finally roof angle $\left(0^{\circ}\right)$ was $46.07{ }^{\circ} \mathrm{C}$. The readings show that even roof angle $\left(60^{\circ}\right)$ recorded highest temperature however the east of this roof angle was lower than roof angle of $45^{\circ}$ and $30^{\circ}$.

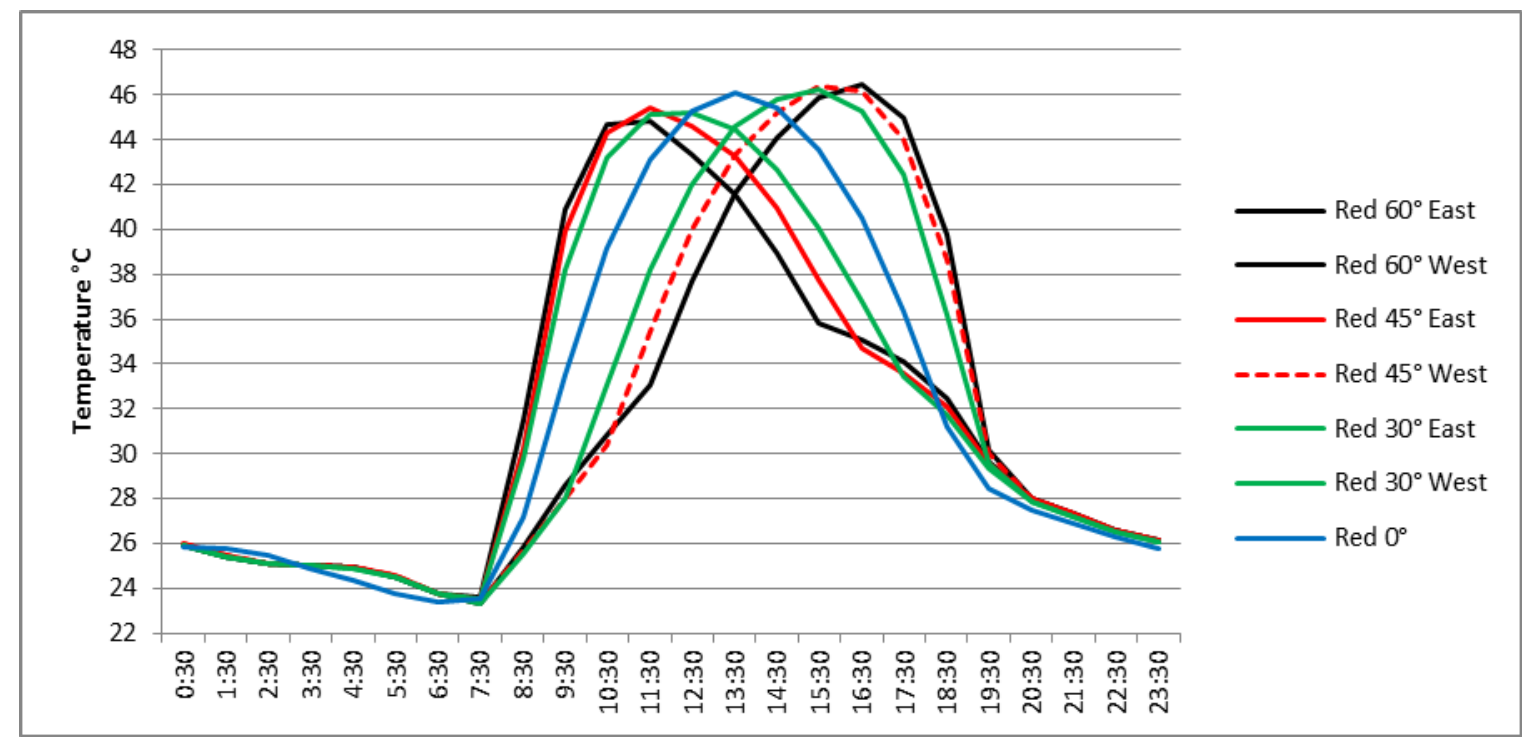

Figure 8. Surface temperature of aluminium sheets with Red colour in two sides (East and West)

Figure 9 for White colour also presents varied patterns for east and west side. The maximum surface temperature was with roof angle $60^{\circ}$ which hit $38.46^{\circ} \mathrm{C}$ around $03: 30 \mathrm{pm}$. The findings indicate that west side was always higher than east side. The results show that maximum reading for roof angle $\left(60^{\circ}\right)$ east side $36.62{ }^{\circ} \mathrm{C}$ and west side $38.46^{\circ} \mathrm{C}$, roof angle $\left(45^{\circ}\right)$ east side $36.9^{\circ} \mathrm{C}$ and west side $38.3^{\circ} \mathrm{C}$, for roof angle $\left(30^{\circ}\right)$ east side $36.97^{\circ} \mathrm{C}$ and west side $37.93{ }^{\circ} \mathrm{C}$ and finally roof angle $\left(0^{\circ}\right)$ was $36.02{ }^{\circ} \mathrm{C}$. The findings in Table 4 affirm that that even roof angle $\left(60^{\circ}\right)$ was recorded highest temperature however the east of this roof was lower than roof angle of $45^{\circ}$ and $30^{\circ}$.

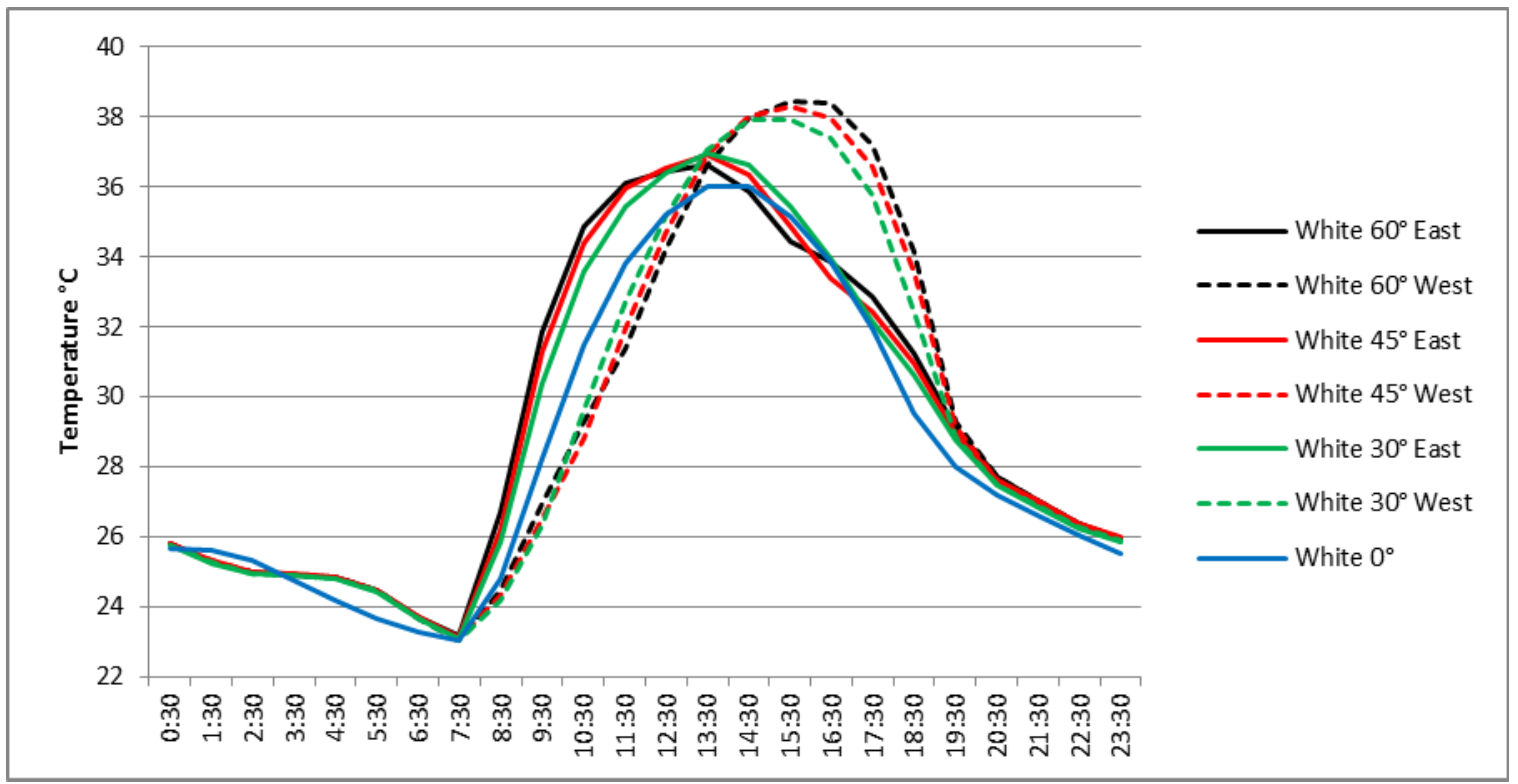

Figure 9. Surface temperature of aluminium sheets with White colour in two sides (East and West) 
Table 4. Surface temperature $\left({ }^{\circ} \mathrm{C}\right)$ for aluminium

\begin{tabular}{|c|c|c|c|c|c|c|c|c|c|c|c|c|c|c|}
\hline & 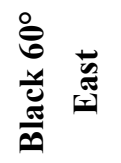 & 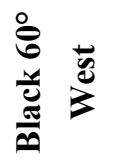 & 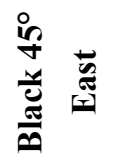 & $\begin{array}{l}\frac{i}{5} \\
\frac{y}{0} \\
\frac{\pi}{\infty}\end{array}$ & 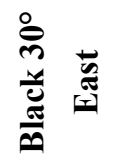 & 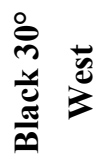 & $\begin{array}{l}\stackrel{0}{0} \\
\frac{y}{0} \\
\frac{\sigma}{0}\end{array}$ & 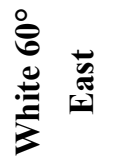 & 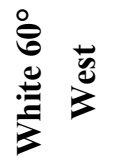 & 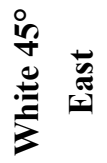 & 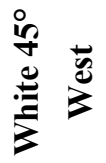 & 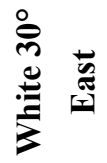 & 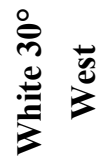 & 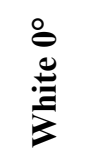 \\
\hline$\sum^{\frac{\pi}{\sigma}}$ & 58.49 & 57.75 & 58.63 & 57.68 & 58.73 & 57.8 & 60.15 & 36.62 & 38.46 & 36.9 & 38.3 & 36.97 & 37.93 & 36.02 \\
\hline$\stackrel{\tilde{E}}{\sum^{\mathbb{E}}}$ & 34.82 & 34.51 & 35.32 & 35.06 & 35.76 & 35.49 & 36.38 & 29.34 & 29.27 & 29.27 & 29.2 & 29.14 & 29.11 & 28.54 \\
\hline$\equiv$ & 23.81 & 23.7 & 23.86 & 23.77 & 23.83 & 23.77 & 23.56 & 23.16 & 23.05 & 23.14 & 23.07 & 23.09 & 23.02 & 23.05 \\
\hline
\end{tabular}

\section{Conclusion}

The paper focuses on different techniques to develop the understanding of pitched roof systems in the tropics. The research hypothesizes that colour approach could change pitched roof angle more than material properties. The results of different roofing systems affirm this theory and show the significance of roof colour more than the roof area, angle and material. Furthermore, it was noticed that pitched roof sides have played a significant role to determine the heat gain. In addition, it was realized that highest temperature for lighter colour was for roof angle $60^{\circ}$ more than lower angles and especially flat roof while for darker colours the highest temperature for roof angle was $0^{\circ}$ or flat roof. Moreover, the results from surface temperature display that even $60^{\circ}$ was recorded the highest indoor temperature for lighter colour such as Red and White however the east side of this roof angle was lower than roof with angle $45^{\circ}$ and $30^{\circ}$. Additionally, the study shows the differences of roof angles with same roof materials found with clay tiles, the difference between roof angles was around $0.71{ }^{\circ} \mathrm{C}$ (Black colour), $0.49^{\circ} \mathrm{C}$ (Red colour) and $0.85^{\circ} \mathrm{C}$ (White colour). However for aluminium sheets was $0.9{ }^{\circ} \mathrm{C}$ (Black colour), $0.36{ }^{\circ} \mathrm{C}$ (Red colour) and $0.89^{\circ} \mathrm{C}$ (White colour). Also with clay tiles the difference of roof colour shows the maximum value for Black - Red roof colour which was $4.48^{\circ} \mathrm{C}$ and for Black - White roof colour was $7.29^{\circ} \mathrm{C}$. However for the aluminium sheets, the reading indicates that maximum record for Black - Red roof colours was $5.08^{\circ} \mathrm{C}$ and for Black - White roof colours was $8.06^{\circ} \mathrm{C}$.

The findings also indicate that the thickness of roof tiles for clay and aluminium sheets have not affected significantly on the behaviour of the temperature patterns. Even though, the pattern of two roof systems (clay tiles $15 \mathrm{~mm}+3 \mathrm{~mm}$ cement board) and aluminium sheet just $(0.8 \mathrm{~mm})$ was similar, the indoor temperature was lower for clay with maximum temperature for Black around $1{ }^{\circ} \mathrm{C}$ and for White colour was $0.28{ }^{\circ} \mathrm{C}$. As a result, the study identifies the passive factors that could help any designer in order to shift the paradigm in the understanding of passive roofing design in the tropical architecture. These results will shed light on more economic decision for optimum roofing design especially for affordable quality housing components in Malaysia.

\section{Acknowledgements}

The authors would like to thank Universiti Sains Malaysia (USM) for the financial support provided for this research project.

\section{References}

Akbari, H., Arthur, H., \& Rosenfeld. (2008). White roofs cool the world, directly offset $\mathrm{CO}_{2}$ and delay global warming. Retrieved from http://www.whiteroofsalliance.org/wp-content/uploads/2010/12/White-RoofsCool-World-2ppNewCntct.pdf

Allen, L. K. K., Elias, S., \& Lim, C. H. (2008). The thermal performance of evaluation of roofing systems and materials in Malaysian Residential Development. Proceedings of SENVAR, ISESEE, Humanity and Technology (pp. 387-395).

Al-Obaidi, K. M., Ismail, M., \& Abdul Rahman, A. M. (2013). An innovative roofing system for tropical building interiors: Separating heat from useful visible light. International Journal of Energy \& Environment, $4(1)$. 
Al-Obaidi, K. M., Ismail, M., \& Abdul Rahman, A. M. (2014). A review of the potential of attic ventilation by passive and active turbine ventilators in tropical Malaysia. Sustainable Cities and Society, 10, 232-240. http://dx.doi.org/10.1016/j.scs.2013.10.001

Bozonnet, E., Doya, M., \& Allard, F. (2011). Cool roofs impact on building thermal response: A French case study. Energy Build, 43, 3006-3012. http://dx.doi.org/10.1016/j.enbuild.2011.07.017

Building Sector Energy Efficiency Project (BSEEP). (2013). Building Energy Efficiency Technical Guideline for Passive Design. Malaysia.

Fitzgerald, W. B., Fahmy, M., Smith, I. J., Carruthers, M. A., Carson, B. R., Sun, Z., \& Bassett, M. R. (2011). An assessment of roof space solar gains in a temperate maritime climate. Energy and Buildings, 43(7), 1580-1588. http://dx.doi.org/10.1016/j.enbuild.2011.03.001

Green Building Index. (n.d.). RESIDENTIAL NEW CONSTRUCTION (RNC). Retrieved from http://www.greenbuildingindex.org/Resources/GBI\%20Tools/GBI\%20Design\%20Reference\%20Guide $\% 20$ -\%20Residential\%20New\%20Construction\%20(RNC)\%20V1.02.pdf

Hadavand, M., \& Yaghoubi, M. (2008). Thermal behavior of curved roof buildings exposed to solar radiation and wind flow for various orientations. Applied Energy, 85(8), 663-679. http://dx.doi.org/10.1016/j.apenergy.2008.01.002

Hadavand, M., Yaghoubi, M., \& Emdad, H. (2007). Thermal exchange of flat and vaulted roofs exposed to solar radiation for various building geometries. Proceedings of the 15th ISME conference, Tehran, Iran.

Integrated Environmental Solutions (IESVE). (n.d.). Home page. Retrieved from http://www.iesve.com/

Jayasinghe, M. T. R., Attalage, R. A., \& Jayawardena, A. I. (2003). Roof orientation, roofing materials and roof surface colour: their influence on indoor thermal comfort in warm humid climates. Energy for Sustainable Development, 7(1), 16-27. http://dx.doi.org/10.1016/S0973-0826(08)60345-2

Mahdavinejad, M., Ghasempourabadi, M., Nikhoosh, N., \& Ghaedi, H. (2012). The Role of Roof Shapes in Design of Green Building Systems (Case Study: Iran, Tehran). International Conference on Future Environment and Energy IPCBEE, 28 (2012). Singapoore: IACSIT Press.

Pearlmutter, D. (1993). Roof geometry as a determinant of thermal behavior: A comparative study of vaulted and flat surface in a hot-arid zone. Architect Sci Rev, 36(2), 75-86. http://dx.doi.org/10.1080/00038628.1993.9696740

Pisello, A. L., \& Cotana, F. (2014). The thermal effect of an innovative cool roof on residential buildings in Italy: Results from two years of continuous monitoring. Energy and Buildings, 69, 154-164. http://dx.doi.org/10.1016/j.enbuild.2013.10.031

Rahman, A. M. A., Rahim, A., Al-Obaidi, K., Ismail, M., \& Mui, L. Y. (2013). Rethinking the Malaysian Affordable Housing Design Typology in View of Global Warming Considerations. Journal of Sustainable Development, 6(7).

Runsheng, T., Meir, I. A., \& Etzion, Y. (2003). An analysis of absorbed radiation by domed and vaulted roofs as

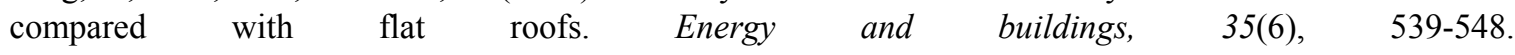
http://dx.doi.org/10.1016/S0378-7788(02)00165-2

Vijaykumar, K. C. K., Srinivasan P. S. S., \& Dhandapani S. (2007). A performance of hollow tiles clay (HTC) laid reinforced cement concrete (RCC) roof for tropical summer climates. Energy and Buildings, 39, 886-892. http://dx.doi.org/10.1016/j.enbuild.2006.05.009

Yacouby, A. M. A., Khamidi, M. F., Nuruddin, M. F., Farhan, S. A., \& Razali, A. E. (2011). Study on roof tile's colors in Malaysia for development of new anti-warming roof tiles with higher Solar Reflectance Index (SRI). In National Postgraduate Conference (NPC), 2011 (pp. 1-6). IEEE. http://dx.doi.org/10.1109/NatPC.2011.6136358

\section{Copyrights}

Copyright for this article is retained by the author(s), with first publication rights granted to the journal.

This is an open-access article distributed under the terms and conditions of the Creative Commons Attribution license (http://creativecommons.org/licenses/by/3.0/). 